\title{
'Giusta la benefica intenzione del Re': the Bourbon Cowpox Vaccination Campaign in Sicily
}

Sicily $[. .$.$] acquired the vaccine through the intervention of the Sea.$ (Moore; 1815, p. 266)

\author{
John Chircop
}

\section{Introduction}

Whis study starts by contextualising the arm-to-arm, sea-borne, transfer and diffusion of the cowpox vaccine in Sicily in the war conditions of the early 19 th century which led to a new geopolitical configuration of the central Mediterranean - this being reflected in the island's troubled transition from French occupation to a British protectorate and its subsequent integration in the Kingdom of Two Sicilies. Against this backdrop, the Bourbon monarchy enthusiastically sanctioned Edward Jenner's cowpox vaccination method and launched it as one of its principal public projects. What follows is an analysis of the intricate links which this mass vaccination campaign came to have with the prevailing state ideology and the power structures of the Regno - with specific reference to Sicily.

Delineating the research parameters of this study, Sicily provides us with what could be termed the 'peripheral experience' of a public health operation which emanated from the state centre of power - in Naples - and unfolded throughout the Southern Italian territories, passing through a chain of intermediating institutions and local representatives, and eventually encountering a popular culture very much suspicious of the intentions of the monarchy. Picturing the whole campaign from this peripheral experience provides a vantage point from where to investigate the multifaceted encounters which this state mass immunisation campaign had with this island's environmental, social and cultural landscape.

By examining this public health vaccination campaign in the specific conditions and political economy of Sicily during the Restoration period, it will be possible to make a thorough analysis of what prima facie seemed a veritable paradox: that of 
having a conservative Bourbon government adopting the most advanced medicine just discovered, and organising one of the earliest examples of state-sponsored noncompulsory immunisation programmes in history. This line of investigation equally helps to bring to the fore and investigate the role played by the counter-reformist Roman Catholic Church, particularly at the parish level, as well as the part played by religious belief and ritual, and the role of the parish priests, in the spread of the vaccinae in their communities. Moreover, focusing on the intricate connections which the vaccination campaign against smallpox came to have with the prevailing power structures of the state, Church and other power institutions, lands us straight into the historiographical debate on the mezzogiorno during the Restoration period, and more specifically in that concerning the history of public health in Sicily before Italian unification. For these last thirty years or so, revisionist historians have been highly critical of the previous Meridionalismo theoretical paradigm, which framed the history of the South during the Restoration period, as lacking a historical appreciation of the complex structures of administration adopted by the Bourbon regime, by and large presenting it as one which tried to turn back the clock to preNapoleonic times. Revisionist historians, equipped with more theoretically elaborate methods, taking a wider comparative approach, and relinquishing the strong ideological attachment of the previous Meridionalismo historical school, have been painstakingly reconstructing the pre-unification period, paying particular attention not to gloss over the social, cultural and economic distinctions of the territories making up the kingdom of Two Sicilies - most particularly when it comes to Sicily. ${ }^{1}$ The ensuing archival-based corpus of historical literature relating to the various aspects of the Bourbon monarchy's government and its institutions demonstrates this regime's attempts to combine a deeply entrenched conservatism with a drive for administrative modernisation, particularly in the fiscal system and in public health. ${ }^{2}$

This new approach to southern Italian - and Sicilian - history has spurred a growing scholarly interest in the history of public health of this region in general. However, relatively little has been published on the social, cultural and political

1 See for instance Piero Bevilacqua, Breve Storia dell'Italia Meridionale dall'Ottocento a oggi (Roma, 1993); P. Pezzino, Un paradiso abitato dai diavoli. Societa', elites, istituzioni nel mezzogiorno contemporaneo (Milano, 1992), pp. 98-101; A. Scirocco, 'L'Amministrazione Civile: istituzioni, funzionari, carrieri' in A. Massafra ed., Il Mezzogiorno preunitario. Economia, Societa $e$ Istituzioni (Bari, 1988), pp. 365-378. Cf. also papers in John A. Davis and Paul Ginsborg eds., Society and Politics in the Age of the Risorgimento. Essays in Honour of Denis MackSmith (Cambridge, 1991).

2 Jonathan Morris, 'Challenging Meridionalism. Constructing a New History for Southern Italy' in Robert Lumley and Jonathan Morris eds., The New History of the Italian South. The Mezzogiorno Revisited (Exeter, 1997), pp. 8-9. 
issues surrounding the Bourbon cowpox vaccination campaign in Sicily, ${ }^{3}$ in spite of the pivotal part it played in the modernisation of the public health sector there. Definitely, this has not been caused by a lack of accessible primary documentation. The Archivio di Stato in Palermo holds the voluminous records of the Commissione Centrale di Vaccinazione (Central Commission for Vaccination), which managed the immunisation campaign on the island. This documentation has actually provided the bulk of the primary sources used to investigate the principal issues treated in this study, starting from the more structural ones - such as the multi-functioning of the network of the provincial and communal vaccination commissions; to issues of human agency - which include the roles played by the official vaccination agents and local state representatives (the mayor or sindaco and the intendente); but also the organisational, cultural and human difficulties met by all these campaign agents in various parts of Sicily. These detailed records also enable a lively and nuanced reconstruction of the daily practices of the public vaccinators, the local parish priests and the midwives, who immediately emerge as protagonists of this vaccination campaign within the neighbourhoods and the households - providing deeper insights into the constraints, the various modes of cooperation and the conflicts they faced in their daily tasks. As this research approach gives importance to human issues -including subjective perceptions - found in this mass vaccination experience, the underlying people's perspective of this study starts becoming evident. It becomes even more so when touching on matters which are usually not treated, such as the exploitation of vulnerable foundlings and orphans as part of this campaign, or the people's mixed feelings and varying reactions to this 'new inoculation' method. The variolea vaccinae was, after all, intended for and applied on sensitive individual bodies.

\section{Transferring Cowpox Vaccine to Sicily}

As happened on many other historical occasions, when warfare served as a catalyst for the rapid transfer of new medical inventions, so did the Anglo-French Wars (more specifically the British naval-military campaign against the French in 1801) convey Edward Jenner's cowpox vaccination ${ }^{4}$ to the Central Mediterranean. Variolae Vaccinae, proclaimed as an extraordinary preventive medicine, immediately attracted the attention of the British army authorities and the Admiralty, which

3 One significant work dealing with this subject being P. Pierri, 'La vaccinazione antivaiolosa nel Regno delle due Sicilie', in Archivio storico per le province napolitane, CVI, 1988, pp. 409-418.

4 Edward Jenner, a British physician, discovered that cowpox virus conferred immunisation against smallpox in 1796 and divulgated his ideas and method with his book An Inquiry into the Causes and Effects of Variolae Vaccinae (London, 1789). 
prefigured its use to immunise their military and naval corps deployed overseas in circumstances of conflict and empire building against one of the most atrocious contagious diseases which was known to decimate legions. Following a successful trial on a batch of eleven sailors, ${ }^{5}$ orders were given to start vaccinating the British naval crews serving on board the fleet, and the forces stationed in the various ports, of the Mediterranean. This medical procedure was left in the hands of Joseph Marshall and John Walker, both doctors and 'missionaries' of Jenner's cowpox method. They left Plymouth accompanying a naval expedition to Egypt with a supply of the variolae, a fresh stock of which was secured for this long voyage by the 'inoculation' of a low rank sailor and probably a couple of boys who were recruited and taken aboard for this purpose. ${ }^{6}$ Once it was proved safe and did not disturb or hinder the sailors' duties on board, ${ }^{7}$ the vaccine was approved and adopted on all warships forming the fleet. Transferred arm-to-arm, with the 'virus' reproducing itself in each person, the cowpox vaccine matter was carried to and introduced in Gibraltar, Minorca and Malta - all being under British control and lying on the strategic route to the East. After immunising the garrisons stationed in each of these colonial ports, the vaccine was provided free to the native populations coming in direct contact with them ${ }^{8}-$ the procedure by which it was introduced being very similar. The colonial governors and crown representatives in each of these outposts authorised the first trials to be conducted on native foundlings and orphans, ${ }^{,}$these being the bodies upon which such medical experiments were usually performed before risking the great majority of (legitimate) children. ${ }^{10}$ Confined in institutions, these infants were easily available for experiment and to be used as human sources to supply fresh cowpox matter at a time when it was difficult to preserve it for any length of time. Each trial was conducted under the watchful eyes of native medics

5 The Evidence At Large, As Laid Before the Committee of the House of Commons respecting Dr Jenner's Discovery of Vaccine Inoculation: together with the Debate which followed and some observations (London, 1805), p. 64; James Moore, The History of the SmallPox (London, 1815), p. 266.

6 Abate Bellet D.S.], Continuazione Di Fatti e D'Osservazioni Intorno al vaiuolo Della Vacca fatta da Odoardo Jenner (tradotto dal Inglese in Italiano) (Malta, 1801), p. 30; Paul Cassar, 'Edward Jenner and the Introduction of Vaccination in Malta', Medical History Journal (January, 1969), 13, 1, p. 70; Ian Glynn and Jenifer Glynn, The Life and Death of Smallpox (Exmouth, 2005), p. 121; Moore, p. 265.

7 The Evidence, p. 66.

8 For the introduction of cowpox vaccine in Gibraltar, Malta and Minorca see Sam Benady, Civil Hospitals and Epidemics in Gibraltar (Gibraltar, 1994), p. 94; John Hennen, Sketches of the Medical Topography of the Mediterranean comprising an Account of Gibraltar, The Ionian Islands and Malta (London, 1830), p. 118; Cassar, pp. 70-71.

9 Cf., The Evidence, p. 66.

10 [Abate Bellet], p. 29; Glynn, pp. 121, 168-169. 
and surgeons to convince them of the beneficial outcome of the vaccine, and to instruct them in Jenner's cowpox principle and practical method. ${ }^{11}$

Parting ways in Malta, Doctor Walker continued his journey, accompanying the expedition to Egypt in order to vaccinate the British forces deployed there, while Joseph Marshall crossed to Sicily, then also under British protection. ${ }^{12}$ In Palermo, where a recent smallpox epidemic had just left over 8,000 persons dead and many others blind and disfigured, the vaccine was enthusiastically received by the Bourbons whose recent dynastic medical history included family members who had died or carried the scars left by the disease. Most notably, Jenner's cowpox vaccination method was sanctioned by the potent Catholic Church which proved to be a driving force behind the launching and the long-lasting campaign in Sicily. Marshall took over a Jesuit seminary in Palermo and turned it into a vaccination hospital, run on the same lines as that established in Malta. As he himself related, the first vaccination successes in Sicily 'excited a strong desire for its practice in Naples where the small pox has always been considered as very fatal'. ${ }^{13}$ Crossing over to Naples, he founded the Istituto di Vaccinazione Jenneriana (Institute for Jennerian Vaccination), which served as a medical clinic for the cultivation of the cowpox lymph and as a vaccination school from where medics carried 'both the knowledge of the disease and means for the practice of it, into their respective provinces. ${ }^{14}$ From here the vaccine was introduced in the towns and villages around Sicily, and to such islands as Pantelleria, ${ }^{15}$ again using orphans and foundlings for trials and as carriers of the cowpox matter.

With the Restoration of the Kingdom of Two Sicilies under King Ferdinand 1 in $1815,{ }^{16}$ cowpox vaccination, which was already being practised, was taken up by the

11 Besides being instructed in the use of this preventive medicine, local physicians were introduced to Jenner's medical ideas and method through the publication of books and manuals. These included one authored by Joseph Marshall himself, Sul vaiuolo vaccinico (Palermo, 1801), as well as a translation in Italian of Edward Jenner's book, A Continuation of Facts and Observations, translated by Abate Bellot in Malta during the same year with the title Continuazione Di Fatti e D'Osservazioni Intorno al vajuolo Della Vacca fatta da Odoardo Jenner (tradotto dal Inglese in Italiano dall' Abate Bellet D.S. (Malta, 1801).

12 R.T. Wilson, A Narrative of the British Expedition to Egypt (London, 1803), pp. 2-3.

13 The Evidence, p. 66.

14 Ibid., pp.65-66. Marshall reported that he performed more than 10,000 vaccinations in all.

15 Although by 1829 no cases of smallpox were reported in Pantelleria, the intendenza of Trapani decided to send a ready vaccinated foundling: 'nella prossima primavera avra' cura anche un bambino proietto inoculato in questa di spedire in quest'Isola, per cosi far propagare cola' la vaccinazione' (cf. 'Stato generale dei Vaccinati nel 1829', Intendenza, Valle di Trapani , no. 3131, 12 Mar., 1830 [All correspondence referred to in this paper is incoming, if not otherwise stated. All documents hereafter are taken from the records of the Commissione Centrale di Vaccinazione at the Archivio di Stato in Palermo].

16 With the Vienna settlement, Sicily and Naples were integrated in the Kingdom of Two Sicilies under the Bourbon King Ferdinando IV (thus becoming Ferdinando I), who entered Naples in June 1815. 
new regime as one of its principal public projects, and actually the one which the Bourbons would come to be identified with by many sectors of the population. For the monarchy, providing free vaccination against smallpox meant assuring as much as possible the healthy reproduction of its subjects which, according to its entrenched mercantilist principles, was fundamental for the consolidation of the king's authority. In practical terms, mass immunisation fitted well in the regime's power strategy, being used to secure a modicum of control over larger sections of the poor populace, and to foster social consent to its rule. Cowpox vaccination was indeed continuously represented as the most intimate charitable act of the Bourbon monarchy directed towards each and every one of its poor subjects. Thus in the towns and villages it was announced with such phrases as: 'La vaccinazione, giusta la benefica intenzione del $R e^{17}$ - presenting a notion which would impregnate most of the monarchy's discourse of charitable benevolence accompanying the spread of the cowpox vaccine throughout the Kingdom.

Actually, the Bourbon proclamation of cowpox vaccination to the people in paternalist, benevolent, terms was preceded by the British, whose conveyance of this vaccinae across the western Mediterranean to Sicily had been couched in a colonial discourse of the civilising mission, which presented its benefits to the human body as representing their munificence towards these southern people. One contemporary British author, James Moore, clearly expressed this view in an address to the Sicilian people:

[You] fortunate people that [have been] rescued from the conquest might [now] also be preserved from small pox ${ }^{18}[\ldots]$. Unlike the black Africans with their [...] uncultivated, undeveloped, mental facilities [who] are only a little superior to those of the animals which range the desert [and who] probably must long remain in a great measure deprived of the preventive of small pox. ${ }^{19}$

Essentially, according to this civilising discourse, cowpox vaccination was meant to be a step further in civilising the body and bringing order in society - an idea which was appropriated and further elaborated by the Bourbon monarchy in its own image and for its own ends.

17 Commissione Provinciale Vaccinica, Valle di Catania, no. 3, 26 July 1819.

18 Moore, p. 266.

19 Ibid., p. 273. 


\section{Bourbon Vaccination Strategy and the Modernisation of the Public Health System}

With the Restoration, Sicily came under the Bourbon monarchy's highly hierarchical administrative system, controlled from Naples, ${ }^{20}$ which was itself a legacy left by the previous Napoleonic regime but which in reality, as John A. Davis argues, had already made itself evident as from the second half of the 18th century. ${ }^{21}$ As a consequence, from its previous position as the historical capital of Sicily, Palermo was reduced to one of seven administrative centres. Loss of autonomy, coupled with a series of unpopular government measures, starting with the imposition of conscription, ${ }^{22}$ provoked intense anti-Bourbon opposition which would burst in a series of rebellions. ${ }^{23}$ This in turn pressured the regime to hand over a measure of administrative power to the Sicilian elites, not least with the creation of a Ministry for Sicily which, for a period of time, ${ }^{24}$ provided the necessary impetus for the initiation of badly needed public projects, mainly the construction of a road network (which was designed to connect Palermo with the urban centres of Messina, Siracusa, Girgenti and Trapani), ${ }^{25}$ and the reorganisation of the public health system - two public ventures which were closely interconnected. Concurrently, the state aimed to modernise the administration of the fiscal apparatus and the multi-institutional charitable system. ${ }^{26}$ These reforms would boost the state's share in the control of the dense network of charity establishments, hospices and hospitals which existed throughout the Mezzogiorno, including Sicily. But although these initiatives were founded on the legal principles set by the previous French Murratian administration, even the first public health decrees (that of 14th September 1815, followed by those of February and December 1816) reflected the specific social and cultural circumstances of southern Italy, foremost of

20 Stuart Woolf, History of Italy 1700-1860. The Social Constraints of Political Change (London-New York, 1991), p. 241.

21 John A. Davis, 'Health, Cure and Poor Relief in Southern Europe in the 18th and 19th Centuries' in Ole Peter Grell, Andrew Cunningham and Bernd Raeck eds., Health Care and Poor Relief in 18th and 19th Century Southern Europe (Aldershot, 2005), p. 19.

22 Ibid., pp. 19-20.

23 Vittorio Geijeses, La Storia di Napoli dalle origini ai nostri giorni (Napoli, 1978), pp. 729-30.

24 G. Botti, 'Strutture Sanitarie e malati nell'Ottocento borbonico', in Massafra, pp. 122123.

25 Although plans were laid during this period, it took several decades for the main roads to be finished (G. Perez, 'La Sicilia e le sue strade' (Palermo 1861) in C. Trasselli ed., Un Secolo di politica stradale in Sicilia (Roma-Caltanisetta, 1963).

26 On the ways in which the Bourbon government attempted to deal with the problem of poverty and beggary in the Regno, especially in Naples, cf. Lucia Valenzi, 'Linee di Intervento del governo borbonico nei confronti della poverta', in Massafra, pp. 1207-1215.

27 Ibid., pp. 1211-1212. 
which was the political imperative to maintain the thick layer of poor relief and public health services founded on the traditional principles - and state ideology - of public charity. In this context, the law of the 20th October 1819, entitled Legge organica sulla publica salute ne' domini di qua e di la' del Faro, was designed to generally augment the presence of the state in most matters dealing with hospitalisation and public poor relief, leading to a more equal and balanced State-Church relationship - this being considered essential for the upkeep of the Restoration monarchy. In substance, therefore, the on-going legislative reforms which were intended to both modernise the administration of the public health system and strengthen the state ideology of benevolent charity, produced what historians G. Botta and V. Barbati describe as 'one of the most analytic and detailed [legislative frameworks] from those of the pre-unification states' in Italy. ${ }^{28}$ At the same time, of course, this intensified state assistenzialismo of an already financially onerous public health and poor relief system.

However, as much as these legislative-administrative initiatives consolidated the state's universal charitable ideology and increased its share in the management of the bulky layer of charitable institutions, they also prompted the application of new scientific ideas in public health, as observed with the efforts made to separate the mentally ill from the sick others; with the setting up of hospitals based on modern clinical practice for the observation and cure of the sick (in contrast to the old poorrelief idea of maintaining charity institutions for the indiscriminate sheltering of the sick, the old and the infirm); and with the training of doctors in modern clinical medicine. $^{29}$ In all of this, the cowpox vaccination campaign played a leading part, instilling the fresh principle of preventive medicine, while still employing the conventional protectionist ideas of public sanitation, such as forced isolationism and quarantine. ${ }^{30}$ In this sense, the implementation of this programme represented the Bourbon regime's wider political-public health strategy. Brought under the auspices of the Royal family and provided with a territory-wide network of vaccination committees, confirms the political weight which the Bourbon regime put on this mass vaccination campaign.

Consequently, when it came to Sicily, this non-compulsory vaccination programme would prove to be one of the most tangible projects realised by the Bourbon administration, making itself directly felt in each community and in the households, within a social landscape where the state was commonly perceived as remote from local affairs. While immunising the Sicilian population against one of

28 V.Barbati, 'L'Igiene Pubblica in tempi anormali', in Atti del Congresso celebrativo del centenario delle leggi amministrative di unificazione (Vicenza, 1967), vol. 2, p. 157.

29 Laura Guidi \& Lucia Valenzi, 'Malattia, Poverta', Devianza Femminile. Follia nelle Istituzioni Napoletane di Pubblica Beneficenza', in Massafra, pp. 1179-1180.

30 Commissione Provinciale di Vaccinazione, Valle di Messina, no. 174, 31 Dec 1827; Cf. also Peter Baldwin, Contagion and the State in Europe, 1830-1930 (Cambridge, 2005), p. 246. 
the worst contagious diseases in existence, this campaign also intended to extend and sharpen the state's biopolitical practices in this part of the Kingdom, confirming how, as James C. Riley noted, health prevention and social surveillance complemented each other in the implementation of public health projects in history. ${ }^{31}$

The vaccination campaign itself was structured on, and intertwined with, all levels of the state administrative structure and power hierarchy, including the local state agencies and representatives throughout the Kingdom's territories. In Sicily, the whole project was managed by the central commission for vaccination (Commissione Centrale di Vaccinazione) in Palermo, which was established by the royal decree of the 20th of October 1818 and operated through an island-wide network of commissioni at the provincial and communal levels (commissioni proviniciali and commissioni comunali), with the capillary ends of the network being the local vaccination boards or giunte di vaccinazione. Each giunta was made up of the mayor (sindaco), any other state functionary on the spot, as well as the vaccinator and the parish priest. Their main responsibility lay in vaccinating as many inhabitants as possible in their localities. They were to meet regularly and see that all quarterly statistics where properly kept and sent to the centre. ${ }^{32}$ Besides, they were to regularly report back to the intendenza and the central commission of vaccination in Palermo on matters directly related to the progress or otherwise of the cowpox vaccine in the communities under their care. ${ }^{33}$ Notwithstanding such multiple duties, these local giunte depended on the comune for basic resources, including the provision of public vaccinators and supplies of fresh vaccine. Made up of persons elected from lists of local power figures, from the landowning and professional elites, and nominated by the state, the commune was given control of the fiscal affairs, policing, public works and public health, but with all decisions needing the final approval of the intendente. This led the vaccination campaign to become inextricably tied to local politics, revolving around the intendente who articulated what Robert Putman terms the deeply rooted local 'vertical networks of hierarchy'. ${ }^{34}$ This meant that the reach of the political contacts of the intendente, and his abilities to negotiate with the central commission of vaccination and with the different levels of the government bureaucracy, could make all the difference when it came to

31 James C. Riley, Rising Life Expectancy. A Global History (Cambridge, 2001), p. 71.

32 'Per la rimessa delle mappe quadrumestrili di vaccinazione' [printed circular]. Enclosure in Commissione Provinciale di Vaccinazione, Messina, no. 423, 29 Apr 1830.

33 'Per vaccinarci subito tutti gli individui che non lo sono', ibid.; Dall'Intendente(Duca di Samatino), Intendenza, Valle di Catania, no. 1816, 22 July 1819.

34 Robert Putman, Making Democracy Work. Civic Traditions in Modern Italy (Princeton, 1993), p. 16. 
secure provisions required for vaccination in any commune, in circumstances in which these were not easily forthcoming. ${ }^{35}$

The pivotal role played by the intendente in this campaign is illustrated by the fact that it was through his office that the fresh supplies of cowpox lymph, or "pus vaccinico' as it was locally called, usually passed. ${ }^{36} \mathrm{He}$ was the person responsible to make this vaccine available to the mayors ${ }^{37}$ and the local vaccinators, ${ }^{38}$ as well as to supervise the work of the giunte di vaccinazione, oversee the actual immunisation process in the communes, ${ }^{39}$ and report back to both the provincial and the central commissions. ${ }^{40}$ The intendente was also to make available the communal hall as an 'inoculation centre', if no local hospital existed, to circulate official notices and to use all other means available to inform the public as to the time and place to vaccinate their children. ${ }^{41}$ Moreover, he was duty-bound to present himself on site where natural smallpox outbreaks occurred, ${ }^{42}$ and apply his authority to call out the police and ask for military assistance to stop contagion and to keep public order. ${ }^{43}$ Records show the intendenti usually taking a hard line attitude. Believing in the old protectionist sanitary principles, ${ }^{44}$ they were very much inclined to instantly employ quarantine - 'per impedire contatto con gli ammalati - and to use force to isolate households or whole neighbourhoods, and to find an isolated place where to enclose the diseased'. ${ }^{45}$ Although they were key agents of the state vaccination campaign in their communes, the intendenti were to seek the advice and collaboration of locally respected personalities, including the mayors (sindaci) and the parish

35 On the unequal distribution of these basic resources cf. Intendenza, Valle di Palermo, no. 5173, 7 Apr.1827; 'Stato di Vaccinazione', Intendenza della Valle di Palermo, no. 16802, Apr 1829. See also conclusion below.

36 Intendenza, Valle di Palermo, no. 3595, 12 Mar 1827.

37 Commissione Vaccinica, Valle di Catania, no. 34, 3 Sep 1829; Intendenza, Valle di Palermo, no. 16802, 10 Oct 1829.

38 Intendenza, Valle di Palermo, no. 5173, 7 Apr 1827; 'Stato di Vaccinazione', Intendenza, Valle di Palermo, no. 1680, 1 Oct 1829.

39 'Interessa il Sigr. Intendente a far metter a disposizione della giunta della sezione i gendarmi' (Commissione Vaccinica, Valle di Catania, no. 2304, 7 June 1830); Senatore delle sezione del molo, Intendenza, Palermo, no. 92, 20 Apr 1827.

40 Commissione Vaccinica Provinciale, Siracusa, no. 116, 27 Aug 1827 and no. 136, 27 Dec 1827.

41 Commissione Provinciale di Vaccinazione, Messina, no. 43, 10 Mar 1823.

42 'Per Vaccinarsi subito tutti gli individui che non le sono stati' [printed circular], Commissione Provinciale di Vaccinazione, Messina, no. 423, 29 Apr 1830.

43 I componenti della Commissione al Sindaco Preside. della Giunta Vaccinica di Messina, no. 423, 29 Apr 1830; Intendenza, Valle di Palermo, no. 9981, 12 July 1827.

44 Intendenza, Valle di Palermo, no. 4040, 21 Mar 1827; Commissione Provinicale di Vaccinazione, Valle di Messina, no. 174, 31 Dec 1827.

45 Commissione Provinciale di Vaccinazione, Valle di Messina, no. 174, 31 Dec 1827. 
priests, ${ }^{46}$ who had a more intimate knowledge of the communities under their care and who were better versed in the customs and mentality of the local people.

\section{The Vaccinator, the Parish Priest and the Midwife}

When it came to the actual vaccination procedure in the community, the public vaccinator was certainly the key person. After being instructed in Jenner's cowpox method, doctors obtained a vaccination warrant from the provincial commission of vaccination, and were sent to any town, village, or sezione of the larger urban centres ${ }^{47}$ where their duties were required. ${ }^{48}$ One of their first tasks was to seek the cooperation of the local parish priest, the local physicians - if any - and the midwives, and watch over them to make sure that they were 'abiding by their duties when it came to introduce the vaccination practice to the people'. ${ }^{49}$ Newly arrived vaccinators were usually instructed to get in touch with the sindaco to be handed a supply of the 'pus vaccinico'. It was standard procedure to start with the local foundlings or orphans ${ }^{50}$ before proceeding to immunise family children and as many other individuals as they were able to, giving precedence to the newly born. With the help of the mayor and the parish priest, this procedure was to be performed either in the local vaccination centre or town hall (on notified days and times of the week), or else by going door to door, as local circumstances dictated. They were also to keep a rigorous record of those whom they vaccinated, fill in the official forms, and send all the statistical data and related information, on a quarterly and yearly basis, to the provincial commission. ${ }^{51}$ They were also to record in detail any occurrence of 'natural smallpox' in any household or neighbourhood under their care, ${ }^{52}$ and to keep a sharp eye on those families who refused vaccination, holding the local giunta and the commissione or intendenza regularly informed. Added to these surveillance tasks, they were also compelled to proceed immediately

46 Commissione Provinciale di Vaccinazione, Valle di Messina, n.n., 10 May 1823; Intendenza della Valle di Palermo, no. 9981, 12 July 1827.

47 Intendenza, Valle di Catania, no. 2049, 31 Jan 1828.

48 I Componenti della Commissione, al Preside. Commissione Provinciale di Vaccinazione, Valle di Messina, 19 Dec 1823. In the meantime, a doctor could be issued with a temporary permit to act as provisional vaccinator ('Della Instruzione del medico comunale provisore', Commissione Provinciale della Vaccinazione, Messina, no. 869, 5 Aug 1830).

49 Commissione Provinciale di Vaccinazione, Valle di Messina, no. 185, 29 Nov 1823.

50 I Componenti della Commissione, al Preside. Commissione Provinciale, Valle di Messina, 19 Dec 1823.

51 Intendenza di Messina, no. 1994, 24 Feb 1823; Commissione Provinciale di Vaccinazione, no. 444, 2 May 1830.

52 Lettera di S. Puli (Pubblico Vaccinatore), al Preside. Commissione di Vaccinazione, Palermo, n.n., 1 Feb 1830. 
to any 'contagion site', isolate the diseased, and vaccinate those coming in contact with them or who lived in their proximity.

To motivate public vaccinators in their 'vaccination crusade', the authorities publicly praised those of them who demonstrated enthusiasm and who put themselves at the forefront of the campaign, ${ }^{54}$ as well as those who experimented with harvesting cowpox lymph from local herds or with new methods for the supply and preservation of 'the virus'. It recommended them to the government for the granting of prices in cash or other official awards or gifts. ${ }^{55}$ Such happened to Dr Domenico Nicotra, public vaccinator in Catania, who in 1806 was one of the first to introduce the cowpox vaccine in that province. By 1827, Nicotra had vaccinated 7,203 individuals, and in 1821 was responsible for setting up the 'commissione sul virus sulla vacca' in Sicily. He was referred to in heroic terms and treated with respect. ${ }^{56}$ In contrast, those public vaccinators, like any other members of the giunta vaccinica, who were found to be negligent in their duties, ${ }^{57}$ were warned, shamed or even suspended in conformity with regulations. ${ }^{58}$ The commissione could either issue a warning or suspend them, ${ }^{59}$ although it seems that in reality it often hesitated to - and usually did not - do so, fearing that this might paralyse the whole campaign in that locality. ${ }^{60}$

The community vaccinator did not only rely on the logistical support (indeed for the supplies of the cowpox vaccine itself) of the intendente and the sindaco, but came under their direct responsibility and supervision. This manifold dependence on the local state representatives frequently proved problematic, as happened in Santa Lucia in 1830, where the mayor was accused of not following standard procedures, thus putting the whole campaign at risk. ${ }^{61}$ Public vaccinators, however, faced other difficulties in their daily tasks. Quite frequently they were not paid on time and did not receive any cash for months - this leading to demotivation and foot-

53 'Per Vaccinarsi subito tutti gli individui che non lo sono stati' [printed circular], Commissione Provinciale di Vaccinazione al Preside. della Giunta, Messina, no. 423, 29 Apr 1830.

54 Commissione di Vaccinazione, Valle di Catania, n.n., 8 Feb 1830.

55 [printed circular], Commissione Provinciale di Vaccinazione, Palermo, no. 423, 29 Apr 1830.

56 Commissione Vaccinica, Valle di Catania, no. 23, 8 Mar 1827.

57 'Dello Sviluppo di vajuolo in una ragazza di campagna di S. Angelo', Commissione Provinciale di Vaccinazione, Messina, no. 916, 19 Oct 1830.

58 'Per Vaccinarsi subito tutti gli individui che non lo sono stati' [printed circular], Commissione Provinciale di Vaccinazione, Palermo, no. 423, 29 Apr 1930.

59 Commissione Provinciale di Vaccinazione, Provincia di Siracusa, no. 136, 27 Dec 1827; Commissione Provinciale di Vaccinazione, Palermo, no. 916, 19 Oct 1830.

60 'Sullo sviluppo del vajuolo in St Angelo in Messina', Commissione Provinciale di Vaccinazione, Messina, no. 916, 19 Oct 1830.

61 'Per vaccinarsi subito tutti' [printed circular], Commissione Provinciale di Vaccinazione, Messina, no. 423, 29 Apr 1830. 
dragging. ${ }^{62}$ Besides, they had to stop their procedures on those many occasions when the vaccine matter was unavailable or when it was received in the wrong - or 'extreme' hot and cold - months of the year, ${ }^{63}$ which they generally perceived as making people, especially infants 'little adapted to vaccination, [and thus having to] leave it to another more docile season'. ${ }^{64}$

Then again, one utmost difficulty encountered by the vaccinatori was their inability to persuade many of the parents to get their children and themselves vaccinated. They commonly faced prejudice, and an aversion to cowpox vaccine, ${ }^{65}$ by households and whole neighbourhoods, partly due to the fact that they were usually outsiders to the community in which they were practising. Their medical scientific notions contrasted, if not dramatically conflicted, with the belief on health and traditional healing practices of the local folk. Many people identified their tasks with the scarification of the skin, and this raised further apprehension ${ }^{66}$ and intensified parents' reluctance to let their children undergo this procedure. All this of course slowed down the pace of immunisation in many localities throughout the island.

When vaccinators were asked by their superiors to explain the causes for the sluggish pace of the immunisation process in their area, they often came to put the blame on the 'ignorance and superstition' of the locals, ${ }^{67}$ this itself showing their incongruence with and inability to comprehend local culture. Although the support of the giunte and the physical presence of the sindaco or the mayor were important to confer an aura of respect to the whole procedure, and to help solve a range of formal difficulties, they made little difference when it came to win over the confidence of reluctant parents. Reports from different locations distant from the capital, as well as from the overcrowded poverty-stricken quarters in the main urban centres, demonstrate that on various occasions many of those families who accepted cowpox vaccination were led to do so following the direct intervention of the local parish priest.

It was common practice for the mayor to ask the parish priest to accompany and to precede the arrival of the public vaccinator in specific neighbourhoods. ${ }^{68}$ As well

62 Commissione Vaccinica Provinciale, Siracusa, no. 116, 27 Aug 1827.

63 'effetto dal calda stagione che agendo fortemente sulla salute de teneri ragazzi' (Intendenza, Valle di Trapani, no. 13796, n.d.; 'per la rigidita' del tempo' (Intendenza, Valle di Palermo, no. 13796, n.d., 12 Mar 1827.

64 'Risultati della Vaccinazione nel periodo di anni otto', L'Intendenza, Valle di Trapani, no. 13796, Jan 1828.

65 Commissione Vaccinica, Valle di Catania, no. 23, 8 Mar 1827; Enclosure in Intendenza, Valle di Trapani, no. 13796, Jan 1828.

66 Giorgio Cosmacini, Storia della Medicina e della Sanita' in Italia (Roma-Bari, 2005), p. 283.

67 Enclosure in Commissione Provinciale di Vaccinazione, Trapani, no. 13796, Jan 1828.

68 Intendenza, Valle di Palermo, no. 19069, 3 Nov 1828; Commissione Vaccinica di Catania, no. 36, June 1830. 
as being present during the actual vaccination, the parroco was also expected to proceed to the site where outbreaks of smallpox had been reported in order to persuade his parishioners to 'take the cowpox vaccine', and to provide a sense of deference to the whole procedure as well as to help in the keeping of public order. ${ }^{69}$ Such active participation of the parish curator in this public health campaign ${ }^{70}$ depended on the respect which the parishioners had towards him as their moral and religious pastor (and as their confessor), as well as their spokesman and mediator ${ }^{71}$ with the state representatives and the local giunta vaccinica.

The parish priests employed a range of persuasion tactics, including that of publicly addressing 'all heads of families' to accept the cowpox during their sermons on the providential benefits accruing from the vaccine. This they did from their church pulpit, from where they also read new regulations and notices regarding the preventive. $^{72}$ They also organised religious processions to accompany the public vaccinators in those poor residential quarters where the people showed aversion to or overtly refused cowpox vaccination. ${ }^{73}$ It seems that this collective religious ritual was employed as early as 1801 to get the poor to accept the cowpox vaccine in Palermo, as vividly described by Joseph Marshall himself in a letter to Edward Jenner:

It was not unusual to see in the morning of the public inoculation at the Hospital a procession of men, women and children, conducted through the streets by a priest carrying a cross, com[ing] to be inoculated. By these popular means it met not with opposition and the common people expressed themselves certain that it was a blessing sent from Heaven, though discovered by one heretic and practiced by another. ${ }^{74}$

Some parish priests employed other means to cultivate trust in the cowpox vaccine, such as soliciting local state representatives to get their children vaccinated in public to serve as an example for the whole community. On one occasion, the curator of a

69 'Sul vajuolo naturale', Intendenza, Valle di Palermo, no. 19069, 3 Nov 1828.

70 For cases of clergy helping out in the vaccination campaign in the other Italian states cf. U Tucci, 'Il vaiolo tra epidemia e prevenzione' in F. della peruta ed., Storia d'Italia, Annali 7 , Malattia e Medicina (Torino, 1984), pp. 410-411.

71 Cf. Antonio Gramsci, Selections from the Prison Notebooks (London, 1970), pp. 5-7, 13-14; L. Allegra, 'Il Parroco: un mediatore fra alta e bassa cultura' in C. Vivanti ed., Storia d'Italia, Annali 4, Intelletuali e Potere, (Torino, 1981), pp. 897-945; Terry Eagleton, Heathcliff and the Great Hunger. Studies in Irish Culture (London, 1996), pp. 77-78.

72 Commissione Proviniciale di Vaccinicazione, Valle di Catania, no. 36, 7 June 1830, 'Sul vajuolo naturale', Intendenza, Valle di Palermo, no. 19069, 3 Nov 1828, for the report by the local giunta with regard to the 'zealous manner in which the local parroco preached in order to persuade the people on the advantages of the vaccine'.

73 Encyclopedia Brittanica 1890 http://reformation.org.1890-britannica.html; Commissione Vaccinica, Valle di Catania, no. 36, 7 June 1830.

74 As quoted in Glynn, p. 121. 
parish in Palermo publicly called upon the sindaci to 'vaccinate their own children as indeed they did' - their example being immediately followed by some five hundred people. ${ }^{75}$

That parish priests were crucial in the immunisation campaign at the community level was confirmed by the central commission's resolution to have them occupy a seat in the local giunte di vaccinazione, together with the mayor and other members from the local elite. ${ }^{76}$ Being formally incorporated in the public health vaccination programme, the parish curators came to be duty-bound by the government health regulations and the tasks imposed by the central commission of vaccination, one of which was to mark and watch over those families who refused the procedure. In this capacity, they were requested by the vaccination commissions to provide them with the 'real numbers' of those children who were not vaccinated in their parish.

The fact that the Vatican had accepted Jennerian vaccination early on, ${ }^{78}$ with Pope Pius VII adopting it in his states in 1814, provided the parish curators with the needed sanction to take an active part in the Bourbon vaccination campaign. Their active participation does not seem to have declined to any substantial measure when, later on, Pope Leone XII (1823 to 1829) expressed himself negatively towards the mass propagation of the cowpox vaccine, ${ }^{79}$ and issued a circular (on 15 September 1824) which revised the Vatican's previously enthusiastic policy, stressing that if practiced, vaccination was to be kept non-compulsory. ${ }^{80}$ The fact that it was never made compulsory in the Kingdom of Two Sicilies was one reason which kept many - although, of course, not all - of the parish curators supportive and active in this campaign.

Yet again, although effective at the parish community level, the influence of the parish priest did not always penetrate all households and convince parents to vaccinate their children. The common folk perceived the parish priest in ambiguous terms, both as their spokesman but also as the official representative of the institutional Catholic Church and (particularly through his connections with the local

75 Il Senatore della sezione dell molo, Palermo, no. 131, 18 June 1827.

76 Il Senatore della sezione del molo, Palermo, no. 432, 24 Apr 1828.

77 Commissione Vaccinica Provinciale, Siracusa, no. 136, 27 Dec 1827.

78 Martin Papenheim, 'The Pope, the Beggar, the Sick, and the Brotherhoods: Health Care and Poor Relief in 18th and 19th Century Rome', in Ole Peter Grell et al, pp. 142-180.

79 Historians have interpreted this as a reactionary move on the part of the Vatican, and of the Pope as being rigorously against Jenner's cowpox vaccination (cf. B. Croce, Storia d'Europa nel secolo decimono, (Bari, 1832), as in Tucci, p. 412). On the other hand there was a strong tradition of Catholic clerical resistance - especially in the schools of theology - against inoculation; see Giorgio Cosmacini, La religiosita' della medicina. Dall'antichita' a oggi (Bari, 2007), pp. 105-108.

80 [Giacomo Tommasini], Raccolta Completa delle Opere mediche dal Professore Giacomo Tommasini uno dei 40 della Societa' Italiana etc.etc. con note aggiunte ed emende tipographice (Bologna, 1836), pp. 19-20. Ordinance of 1824 - which revoked the edict of June 1822. Apart from the rhetoric which he might have uttered against vaccination on several occasions, in actual fact Pope Leo XIII limited his prohibition to compulsory vaccination only (cf. Tucci, p. 412). 
elite and the government functionaries sitting with him in the giunta) as an agent of state officialdom. On many instances, just like the public vaccinator, the parish priest was not native of the place where he was exercising his pastoral duties, and this partly diminished his influence on the parishioners. In such circumstances, the use of moral sanctions and pressures were not always appreciated by the parents, and frequently carried even less credibility with the mothers who were earmarked as the main targets by the regime's vaccination campaign. In contrast to issues relating to the soul, when it came to matters of health and cure of the female and infant bodies, it was the midwife (levatrici or mammane) who carried real weight and influence on the mother's mode of thinking and behaviour, not only during pregnancy and the post-partum period, but throughout her child's infancy. ${ }^{81}$

Unlike many parish priests, midwives were not identified with the all-male vaccination commissions and the giunte by the people. While exclusion from these state regulative and surveillance bodies did not give midwives any official decisionmaking capacities, it, perhaps unwittingly, contributed to solidify the - organic trust and confidence in which they were held by local women, born out of physical and psychological intimacy. To be sure, midwives - being depositories of knowledge on matters concerning female and infant bodies, childbirth and curing practices - were fetched for advice and practical assistance during illness and on matters of contraception and fertility. ${ }^{82}$ Living in the same neighbourhood, they were usually readily available to all females at all times. Of course, it was due to all these factors, especially the esteem they were held in, that the levatrici were instantly identified by the public health authorities as the obvious persons most able to convince mothers that vaccination was safe and beneficial to their infants. ${ }^{83}$ They were seen as those who could override, if not completely eliminate, the prejudice and the fear of vaccination from the households, ${ }^{84}$ both in the rural and mountainous districts as well as in the crammed quarters of the large urban centres throughout Sicily. ${ }^{85}$

81 Cf. A. Gissi, 'Levatrici e controllo delle nascite nell'Europa del Novecento', Medicina \& Storia: Rivista di Storia della Medicina e della Sanita', (2004), 7, pp. 139-166.

82 Ibid.

83 Caterina Tisci, 'Le Levatrici e la diffusion della vaccinazione antivaiolosa nel Regno di Napoli', in Revista Internacional de Culturas \& Literatures (Dec 2005), 3, pp. 1-3. For other parts of Italy, France and Britain cf. Jacques Gelis, 'Quando le donne partorivano senza medico' in Jacques Le Goff and Jean-Charles Sournia eds. Per una Storia delle malattie (Bari, 1986), p. 269; Michael Bennett, 'Jenner's Ladies: Women and Vaccination against smallpox in early nineteenth century Britain', History: the Journal of the Historical Association, vol. 93, 312, pp. 497-98.

84 Commissione Vaccinica, Valle di Catania, no. 23, 8 Mar, 1827; Intendenza, Valle di Palermo, no. 18524, 23 Oct 1828.

85 Y.M. Berce, Le Chaudeon et la lancette. Croyances Populaires et medicine preventive 1789-1830 (Paris, 1984), p. 109; G.Consmacini, 'Curare e aver cura nel primo Ottocento', p. 22. 
The regulations of the central commission of vaccination compelled midwives to assist in all aspects of the vaccination campaign in their locality ${ }^{86}$ as a condition for the renewal of their official warrant. ${ }^{87}$ Those who did not abide by their official duties were to be reported by the local giunta to the intendente who would, after communicating with the Ministero dell Interno, order the protomedico to suspend them from their service. ${ }^{88}$ They were not only required to lay the ground - the social terrain of trust - for the community vaccinator, and to accompany him to the households or lead the parents to the vaccination centre, but were also expected to become knowledgeable about the innesto vaccinico. In this way they were better prepared to educate mothers on the benefits of the vaccine to their newborn, to directly help the vaccinator (both during the procedure and in revaccination), and to be able to act on any negative symptoms observed in vaccinated children. ${ }^{89}$ Additionally, regulations compelled all midwives to keep a watchful eye on the 'state of natural smallpox' in their localities, and to report cases of the disease which they could come to know of during their daily itinerary of family visits. In these instances they were to contact the vaccinator right away and help him immunise those coming in contact with the diseased. ${ }^{90}$ Midwives played all these active roles as part of their daily routine, remaining the first - and usually the only - link between the mothers and the public vaccinator. They also acted as interpreters, explaining the substance of medical discourse, ${ }^{91}$ and inculcated the new principles of prevention and avoidance in relation to smallpox and other contagious disease in their communities.

\section{Slowing Down the Pace: Structural, Cultural and Human Constraints}

The widespread aversion against the cowpox vaccine ${ }^{92}$ proved to be one of the principal problems which slowed down and, in many circumstances, disrupted this campaign. Refusal to be vaccinated was most common among the poorer majority of the people, and indeed it came to be ascribed, by the local civil authorities and

86 Commissione Provinciale di Messina, n.n., 10 May 1823.

87 It was through their active involvement in this mass vaccination campaign that midwives came to be incorporated as a specific category within a highly hierarchical male-dominated medical establishment. They were, of course, subjected to the orders and patriarchal attitudes of the male medics and, in this case, of the public vaccinator.

88 Ibid., p. 2.

89 Tisci, p. 1.

90 Commissione Vaccinica della Valle, Catania, no. 36, 7 June 1830.

91 Gissi, pp. 139-166.

92 Tucci, p. 416; cf. for instance Commissione di Vaccinazione, Valle di Trapani, Cancelleria Comunale di Castelmare, no. 476, 7 Oct 1830. 
by the vaccinators themselves to their 'superstition, prejudice and ignorance'. ${ }^{93}$ Most of the blame was usually put on the 'uncultivated heads of the families', who were normally the ones called upon to take their children to be vaccinated but declined to do so. ${ }^{94}$ Even if the lack of information on the immunisation benefits which cowpox vaccination would provide ${ }^{95}$ played a significant part in this reluctance, in reality this was caused by a multiplicity of factors, including the parents' overwhelming preoccupation with earning a living, ${ }^{96}$ to which 'inoculation' was less of a concern. But there was also the fear of scarifying the infants with the lancet, and the belief that cowpox vaccine would bring about the 'minotaurisation' ('minotaurizzazione') of the human body, or else induce in humans 'diseases of a bovine nature' ( 'i mali propri della natura bovina'). This commonly found anxiety, coupled with a deep mistrust of the local representatives of the state who managed the campaign and frequently of the vaccinators themselves, ${ }^{97}$ contributed to generate further reluctance to - and, on many occasions, outright refusal of - the vaccine. $^{98}$

With collective fear, shame played its part in holding back many of the poor from receiving the cowpox vaccine, especially when this was provided in the town hall. In a locality forming part of the commune of Girgenti, many of the poor villagers who lived in destitution did not respond 'to the beat of the drums' ordered by the sindaco to direct them to be vaccinated in the local cancelleria, 'being so ashamed of publicly showing their misery'. ${ }^{99}$ At the same time, the pride of the handful of local wealthy families led them to resist having their children 'inoculated in a public location', ${ }^{100}$ this of course bringing to a complete halt the whole vaccination programme against smallpox in this community, and prompting the local authorities to reassess their earlier decision to stop public vaccinators from offering vaccination in private homes.

Suspicion of the cowpox vaccine was further engendered by the political instability and the social tensions which prevailed in Sicily - especially in the larger urban centres - throughout the period framing this study, and which were marked

93 'Ignoranza, la superstizione popolare appongono alla vaccine, han saputo a modo degli animi de loro compatrioti, Enclosure in Commissione Provinciale di Vaccinazione, Valle di Trapani, n.n., n.d.

94 Intendenza di Messina, no. 3086, 27 Dec 1827; Intendenza, Valle di Palermo, no. 18214, 20 Oct 1828; Commissione Provinciale di Vaccinazione, Valle di Trapani, no. 13, 31 Jan 1829.

95 Intendenza, Valle di Palermo, no. 18524, 23 Oct 1828.

96 Enclosure, Commissione Provinciale di Vaccinazione, Valle di Trapani, nn. n.d.

97 Giorgio Cosmacini, 'Curare e avere cura nel primo ottocento', pp. 589-627.

98 Intendenza, Valle di Palermo, no. 18524, 23 Oct 1828; Commissione Vaccinica di Catania, no. 23, 8 Mar 1827.

99 Commissione Centrale di Vaccinazione, Palermo, no. 265, Apr 1824.

100 Ibid. 
by the anti-Bourbon rebellions of $1820,1831,{ }^{101}$ and 1837 when a cholera epidemic was followed by a full-blown insurrection in Palermo. After spreading to Siracusa and Catania, this rebellion was brutally repressed by government forces; ${ }^{102}$ yet it was again followed by other outbreaks, the principal ones being the revolt of April 1848 and that of April 1860 in Palermo, which again spread all over the island. In this atmosphere of discontent, anti-Bourbon radical liberals and Sicilian autonomists amplified and manipulated the existing reluctance to vaccination by, for instance, divulgating the myth that the Bourbon monarchy was employing the cowpox vaccine to slowly poison people, as was also attributed to the spread of the cholera epidemic of $1837 .{ }^{103}$

Facing these multiple difficulties, many public vaccinators, together with the local state representatives, recommended to the health authorities to make cowpox vaccination compulsory. This proposal found the support of the provincial commissions of vaccination, ${ }^{104}$ as well as the central commission in Palermo, which came to argue, time and again, ${ }^{105}$ that compulsion would solve the problem of the people's reluctance once and for all, and would rationalise and facilitate the state vaccination programme. ${ }^{106}$ These recommendations were however never implemented by the Bourbon monarchy. ${ }^{107}$

The more structural factors which contributed to the obstruction of the vaccination campaign in Sicily included the already referred to unequal distribution of state financial and public medical resources throughout the island. ${ }^{108}$ From the correspondence and the reports sent by the giunte and the sindaci to the Palermo commission, the unavailability or insufficient number of public vaccinators stands out as one main problem ${ }^{109}$ with, for instance, Messina having only two vaccinators

101 Geijeses, p. 764.

102 A. Forti Messina, 'Il Colera e le condizioni igienico sanitari di Napoli nel 1836-37', Storia Urbana, 3, 1977, pp. 3-4.

103 Ibid.

104'Una legge coattiva che obbligasse i parenti de neofiti a vaccarli spirato appena il primo mese lor eta come aveva anche di obbligo in presentarli all'ufficio dello stato appena nati' Enclosure in Commissione Provinciale di Vaccinazione, Valle di Trapani, n.n., 12 Aug 1829.

105 Tucci, p. 416.

106 Intendenza di Messina, no. 1419, 9 July 1829; Tucci, p. 416.

107 Compulsory vaccination was first adopted in the principality of Piombino (Lucca) in 1806. It would take down to 1888 , in the post-unification period, for it to be made compulsory throughout Italy.

108 Commissione Provinciale di Vaccinazione, Valle di Messina, no. 125, 20 Sep 1827; Commissione Provinciale Vaccinica, Siracusa, no. 116, 27 Aug 1827.

109 Commissione Vaccinica, Valle di Caltanisetta, no. 96, 12 June 1830; Intendenza di Messina, no. 14191, 9 July 1829. 
to service 48 casali in $1829 .{ }^{110}$ The long distances, as well as the undeveloped state of the internal communication/transport system - the flow made worse still by the prevailing political and social instability - throughout the Sicilian territory ${ }^{111}$ continued to severely hamper the rapid dispatch of the preventive vaccine to the local giunte at a time when there was no reliable method to preserve it. ${ }^{112}$ This was coupled with the frequently insufficient quantity or total lack of fresh cowpox vaccine ${ }^{113}$ which disrupted the process of immunisation at the local level, as evidenced by the voluminous letters and reports from Messina, Trapani, Catania and Caltanisetta, with one letter stating that this was 'creating disorders in the process of vaccination'. ${ }^{114}$ Fresh supplies of the variolae, ordered by public vaccinators through their mayor and the Intendenza, on too many occasions took too long to get dispatched in crystal tubes ${ }^{115}$ (which was found to be the best method of transporting the cowpox matter at the time), and arrived on location ${ }^{116}$ frequently 'getting spoilt', owing to the long journey and the hot climate. This evidently complicated matters for the local vaccinator, as it generated further mistrust in the whole campaign. Moreover, as already noted, when the vaccine matter arrived in 'extreme seasons' - high summer or winter - vaccinators were apprehensive of using it on infants, leaving it to 'a more docile season', ${ }^{117}$ by which time it risked becoming ineffective. A routine complaint among the vaccinators was that they did not have enough vaccine available at the right time to be used on the children who were presented to them, and this did not only happen in remote areas but even in the poor quarters of central Palermo. ${ }^{118}$

110 Intendenza di Messina, no. 11193, 23 May 1829; 'Pei Vaccinatori di Messina', Intendenza di Messina, no. 14191, 9 July 1829, leading to many communes having experienced little vaccination (Commissione Vaccinica Provinciale, Siracusa, no. 116, 45 May 1827).

111 Desmond Gregory, Sicily: The Insecure Base. A History of the British occupation of Sicily, 1806-1815, (London-Ontario, 1988), p. 38; On the state of the roads cf. Perez, pp. 82-101; The first plan for a railway in Sicily being made in 1859 (with the first line Palermo-Bagheria (13,337 $\mathrm{km}$ ) starting to be laid down only in 1861 and opening it up in April 1863. The Bourbons were the first in Italy to have constructed a railway (Napoli-Portici) in October 1863 (R. Giuffrida, Politica ed Economia nella Sicilia dell'Ottocento (Palermo, 1980), p. 239.

112 Tucci, p. 417; Glynn, p. 117.

113 'Virus nel Comune di Caltanisetta', L'Intendente, Caltanisetta al Preside. della Commissione Centrale di Vaccinazione, Palermo, no. 3595, 12 Mar 1827; Intendenza, Valle di Palermo, no. 3173, 7 Apr 1827.

114 Commissione Provinciale Vaccinica, Siracusa, no. 116, 27 Aug 1827; 'Stato di Vaccinazione di Palermo', Intendente, Valle di Palermo, no 16802, 1 Oct 1829.

115 Enclosure in Commissione di Vaccinazione, Messina, no. 1205, 18 Nov 1830.

116 Valle di Trapani, Cancelleria communale di Castellamare, no. 1476, 7 Oct. 1830; Intendenza, Valle di Palermo, no. 829, 23 May 1827 and no. 573, 7 Apr 1827; Commando delle Armi in Sicilia (Sezione $4^{\circ}$ ), Palermo, no. 3992, 26 Oct 1828.

117 Cf. Intendenza, Valle di Palermo, no. 3595, 13 Mar 1827; also no. 829, 23 Mar 1827.

118 Intendenza, Valle di Palermo, no. 4040, 21 Mar 1827; Intendenza, Valle di Palermo, no. 17456, 7 Oct 1828; Intendenza, Valle di Palermo, no. 829, 23 Mar 1827. 
As elsewhere, the principal problem encountered by this vaccination campaign to control and eradicate smallpox was related to the epidemiology of this disease. Known to be highly endemic in many parts of Sicily, ${ }^{119}$ this disease favoured the densely populated urban, suburban and remote village living quarters of the poor. In the long term, although showing signs of general abatement, its incidence in many poor neighbourhoods remained high. It mainly carried away or disfigured pre-seven-year-old children who lived in a state of indigence and destitution, such as those inhabiting the overcrowded unsanitary quarters in Palermo, Catania, Siracusa and Messina. ${ }^{120}$ The quartiere Santa Cristina, ${ }^{121}$ the quartiere Sant'Agata in Palermo, and the quartiere de Pizzilari in Messina, as in other comparable neighbourhoods in similar localities and rural villages ${ }^{122}$ throughout Sicily created the ideal conditions for the incubation and spread of vaiola. ${ }^{123}$ Such densely crammed residential quarters not only experienced frequent outbreaks and resurgences of smallpox (which were also due to the neglect of re-vaccination), ${ }^{124}$ but were also the most hard hit during the ferocious smallpox epidemics in Sicily, such as that of 1838-1839. In one of these destitute neighbourhoods, public vaccinators reported that they could not proceed to vaccinate the children who were found undernourished, as their bodies were so 'extremely fragile' that they could not 'take the cowpox'. ${ }^{125}$

Somewhat ironically, these same outbreaks of smallpox, with their horrible death tolls and the loss of sight or disfiguration of those who survived, ${ }^{126}$ as well as the hasty and unceremonious internment of the bodies in unconsecrated grounds, prompted parents to overcome their reluctance and to rush their children to be vaccinated. One such case occurred in Avola in 1827, where the bodies of two infants who died of smallpox were buried in a coffin 'ben lutata con calce ed altro' in uncon-

119 Tucci, pp. 416-417.

120 Intendenza, Valle di Palermo, no. 964, 10 May 1827: 'Informo sull Vajuolo naturale', Il Regio Protomedico Sostituto, no.45, 26 Nov 1827; Intendenza, Valle di Palermo, no. 15940, 28 Oct 1830; Woolf, p. 290.

121 Intendenza, Valle di Palermo, no. 6964, 10 May 1827.

122 'Pello Sviluppo di vajuolo in una ragazza di compagnia di St Angelo', Commissione Provinciale di Vaccinazione, Messina, no. 916, 19 Oct 1830.

123 Intendenza di Messina, no. 3086, 27 Dec 1827; Commissione Provinciale di Vaccinazione, Valle di Messina, no. 1205, 18 Nov 1830; Commissione Provincinciale di Vaccinazione, Valle di Messina, no. 174, 31 Dec 1827; 'Su vajuolo naturale in Avola', Il Regio Protomedico, Commissione Centrale di Vaccinazione, Palermo, no. 45, 26 Nov 1827; 'Il vajuolo naturale in Casalnuovo', Commissione Vaccinica, Valle di Catania, no. 36, 7 June 1830; Intendenza, Valle di Palermo, no. 1957, 30 Aug 1819 (for smallpox occurrence in Montemaggiore); Tucci, p. 402.

124 'Informo sul vajuolo natural in Avola', Il Regio Protomedico Sostituto, Palermo, no. 45, 26 Nov 1827; Gregory, p. 39; Woolf, p. 290.

125 'Risultati della Vaccinazione nella Valle di Trapani', Enclosure in Commissione Provinciale, Valle di Trapani, no. 13796, n.d.

126 Commissione Vaccinica, Valle di Catania, no. 37, 7 June 1830. 
secrated ground, instead of the Catholic parish cemetery - an act which horrified the community and stirred most of the reluctant villagers to take their children to the vaccinator without further ado. ${ }^{127}$ As a matter of fact, collective panic, brought about by such outbreaks of vaiola, ${ }^{128}$ accelerated vaccination in the community in a way that no tactic crafted by the public health authorities and the agents of the vaccination campaign could have ever achieved. ${ }^{12}$

\section{Conclusion}

One general conclusion which can be drawn from this study is that while the Bourbon government invested in an energetic mass vaccination campaign against smallpox, it lacked an accompanying strategy to seriously deal with and reduce the widespread poverty and the unsanitary conditions which most of the people lived in, and which formed the ideal conditions for the frequent outbreaks and spread of vaiola as well as other contagious disease. Neither were the deeply ingrained culture and state ideology of charity-based poor relief ever really challenged, not even with the series of administrative reforms implemented in the public health and poor relief welfare sectors. On the contrary, traditional principles of charitable benevolence were consolidated as a cornerstone of the Bourbon monarchy's state ideology and power strategy, through which it sought to extend social control and foster consent for its rule, particularly in Sicily, where the state was commonly perceived as distant from local affairs. It has been shown how actually the Bourbon regime attempted to amalgamate an entrenched conservatism with efforts at administrative modernisation of the thick layer of charitable establishments, hospitals and poor relief services. Being one of the first massive public projects launched by the Restoration monarchy, this vaccination campaign echoed, and indeed articulated, this combined government agenda - itself introducing the new notion of preventive medicine while employing the more conventional practices - based on state mercantilist protectionist beliefs, which entailed containing smallpox contagion as well as diffusing the cowpox vaccine throughout Sicily.

Moreover, the ways in which this vaccination programme - directed to each individual body - was implemented and operated provided an excellent case study

127 'Vajuolo Epidemico', Il Regio Protomedico Sostituto, Avola, no. 46, 29 Nov 1827; another two dead children were taken by the Capuchin Friars and buried in their grounds, out of the inhabited area.

128 Intendenza di Palermo, no. 1957, 30 Aug 1819.

$129 \mathrm{La}$ Commissione, Valle di Catania, no. 2, 6 May 1819; cf. also Intendenza, Valle di Palermo, no. 4040, 21 Mar 1827; cf. 'Vajuolo in Castiglione e delle misure', Commissione Vaccinica, Valle di Catania, no. 344, 3 Sep 1829; Commissione Vaccinica di Catania, no. 36, 8 Feb 1830. For a similar case in Montemaggiore see Intendenza, Valle di Palermo, no. 1957, 30 May 1819. 
of how prevention and surveillance complemented each other in the history of public health. This has been illustrated by a range of examples which include the systematic gathering of statistics and other information on households and neighbourhoods, the listing and close watching of those who were reluctant to vaccinate their families, and the employment of the police and the military to prevent further contagion and social unrest. In these ways, while immunising the people against smallpox, mass vaccination assisted the Bourbon regime in keeping a modicum of public order in the disturbed Sicilian social and political landscape, although, as this study also shows, this was not always achieved.

On another level, being so intricately intermeshed with the regime's political designs and the prevailing power structures, this vaccination programme became heavily dependent on the state administrative arrangements - at the communal and provincial levels. It also depended on the local representatives (mainly the intendenti and the mayors) who became its pivotal agents on the spot, even for the supply of basic resources, to secure a sufficient quantity of vaccine matter and the needed number of vaccinators in a locality. But on the other hand, narrowing down analysis at the local community and neighbourhood levels, the vital roles played by local personalities clearly emerges. Conjointly with the public vaccinator, who was officially sent to one location or another, the local parish priest and the midwives were pivotal to the spread of the cowpox vaccination in their town, village and neighbourhood. Dedicating a substantial part of its research to the daily practices of each of these protagonists, this study has been able to mark the practices and tasks of each of these personalities, and to measure their weight in the immunisation campaign in their localities. It has shown how, for instance, the public vaccinator, albeit being the one who actually immunised each individual, was frequently unable to convince households to accept the cowpox vaccine in the first place. At this juncture, the local parroco comes out as the one who could persuade his parishioners, in general, of the need to be vaccinated - through his moral and social sway, and by employing a range of persuasive tactics. But even more than the parish curator, it was the midwife, whose trust by the mothers and the family far outweighed the faith which they might have had towards the other two male agents of the vaccination campaign. And, it was mostly due to these mammane that more and more parents came to vaccinate their infants against smallpox, notwithstanding the multiplicity of structural and organisational difficulties which came to hold back, and frequently disrupt, the introduction and spread of this vaccine in the various communes of the island.

Procuring social trust through the art of persuasion was ubiquitous in the complex human experience making up the immunisation campaign of the Sicilian population. Perhaps a significant contribution made by this study is that of having illustrated that, coupled with trust - and indeed mistrust - people's subjective perceptions, both real and the more hazy; their irrational attitudes or religious 
beliefs; shame and pride; their shared world views; and notions of health, care and cure of the body - as expressed either in the fatalistic acceptance of, or the varying measures of fear or reluctance to, vaccination - had a profound bearing on the whole cowpox vaccination campaign in Sicily.

John Chircop is Senior Lecturer at the Department of History, University of Malta. 


\section{References}

Archivio di Stato in Palermo, Palermo, Sicily: 'Commissione Centrale di Vaccinazione', volumes 1-3 (1813-1830).

[Abate Bellet D.S.], Continuazione Di Fatti e D'Osservazioni Intorno al vajuolo Della Vacca fatta da Odoardo Jenner (tradotto dal Inglese in Italiano dall'Abate Bellet D.S.) (Malta, 1801).

Allegra, L., "Il Parroco: un mediatore fra alta e bassa cultura", pp.897-945 in C. Vivanti (ed.), Storia d'Italia, Annali 4, Intelletuali e Potere (Torino, 1981).

Baldwin, Peter, Contagion and the state in Europe, 1830-1930 (Cambridge, 2005).

Barbati, V, "L'Igiene Pubblica in tempi anormali" in Atti del Congresso celebrativo del centenario delle leggi amministrative di unificazione (Vicenza, 1967), pp.150-68.

Benady, Sam, Civil Hospitals and Epidemics in Gibraltar (Gibraltar, 1994).

Bennet Michael, "Jenner's Ladies: Women and Vaccination against smallpox in early nineteenth century Britain" in History: the Journal of the Historical Association, vol.93, no. 312, October, 2008, pp.497-513.

Berce', Y.M., Le Chaudeon et la lancette. Croyances populaires et medecine preventive 1789-1830 (Paris, 1984).

Bevilacqua, Piero, Breve Storia dell'Italia meridionale dall'ottocento a oggi (Roma, 1993).

Botti, G, "Strutture sanitarie e malati nell'Ottocento borbonico", pp. 1221-1230 in Angelo Massafra (ed.), Il Mezzogiorno preunitario. Economia, societa`e istituzioni (Bari, 1988).

— , "L'organizzazione sanitaria nel Decennio", pp.81-98 in A. Lepre, (ed.), Studi sul Regno di Napoli nel Decennio Francese (1806-1815) (Napoli, 1985).

Cassar, Paul, "Edward Jenner and the Introduction of Vaccination in Malta", Medical History Journal, January 1969, 13 (1), 68-72.

Cosmacini, Giorgio, La Religiosita' della medicina. Dall'antichita' a oggi, Bari, 2007.

_ , "Curare e avere cura nel primo Ottocento", chapter from La famiglia italiana dall'Ottocento a oggi (Roma-Bari, 1988), pp. 589-627, downloaded from http://www.formazione.eu.com/-documents/cagranda/ articoli/2001-04-05/articolo.pdf.

—, Storia della Medicina e della Sanita' in Italia, Roma-Bari, 2005.

Davis, John A., " Health Care and Poor Relief in Southern Europe in the $18^{\text {th }}$ and $19^{\text {th }}$ Centuries", pp. 10-33 in Ole Peter Grell, Andrew Cunningham and Bernd Roeck (eds.), Health Care and Poor Relief in $18^{\text {th }}$ and $19^{\text {th }}$ Century Southern Europe (Aldershot, 2005).

Davis, John, A. and Ginsborg, Paul (ed.), Society and Politics in the Age of the Risorgimento. Essays in Honour of Denis MackSmith (Cambridge, 1991). 
Eagleton, Terry, Heathcliff and the Great Hunger. Studies in Irish Culture (London, 1996).

Encyclopedia Brittanica 1890 http://reformation.org.1890-britannica.html.

Gelis, Jacques, 'Quando le donne partorivano senza medico', pp.256-270 in Jacques Le Goff and Jean-Charles Sournia (eds.), Per una storia delle malattie (Bari, 1986).

Geijeses, Vittorio, La Storia di Napoli dalle origini ai nostril giorni (Napoli, 1978).

Gissi, A., 'Levatrici e controllo delle nascite nell'Europa del Novecento', Medicina \& Storia: Rivista di Storia della Medicina e della Sanita', 2004, 7, 139-166.

Giuffrida, R., Politica ed economia nella Sicilia dell' Ottocento (Palermo, 1980).

Giuffrida, Romualdo, "Il problema ferroviario in Sicilia dal 1860 al 1895" in Sicilia e l'Unita' d'Italia. Atti del Congresso Internazionale di Studi Storici sul Risorgimento Italiano (Palermo 15-20 Aprile, 1961) (Milano, 1962), vol.2.

Glynn, Ian and Glynn, Jenifer, The Life and Death of Smallpox (Exmouth, 2005).

Gramsci, Antonio, Selections from the Prison Notebooks [edited and translated by Q.Hoare and G.N. Smith, (London, 1976).

Gregory, Desmond, Sicily. The Insecure Base. A History of the British Occupation of Sicily, 1806-1815 (London-Ontario, 1988).

Guidi, Laura \& Valenzi Lucia, 'Malattia, Poverta', Devianza Femminile. Follia nelle Istituzioni Napoletane di Pubblica Beneficienza', pp.1171-1191 in A., Massafra (ed.), Il Mezzogiorno preunitario. Economia. Societa' $e$ istituzioni (Bari, 1988).

Hennen, John, Sketches of the Medical Topography of the Mediterranean. Comprising an Account of Gibraltar, the Ionian Island and Malta (London, 1830).

Jenner, Edward, An Inquiry into the Causes and Effects of Variolae Vaccinae (London, 1789).

Marshall, Joseph, Sul vaiuolo vaccinico (Palermo, 1801).

Messina, Forti Annamaria, 'Il Colera e le condizioni igienico sanitari di Napoli nel 1836-37', Storia Urbana, 1977, no.3, pp.3-32.

Moore, James, The History of the Small Pox (London, 1815).

Morris, Jonathan, "Challenging Meridionalism. Constructing a New History for Southern Italy" in Robert Lumley and Jonathan Morris (eds.), The New History of the Italian South. The Mezzogiorno Revisited (Exeter, 1997).

Papenheim, Martin, "The Pope, the Beggar, the Sick, and the Brotherhoods: Health Care and Poor Relief in $18^{\text {th }}$ and $19^{\text {th }}$ Century Rome", pp.142-163 in Ole Peter Grell, Andrew Cunningham and Bernd Roeck (eds.), Health Care and Poor Relief in $18^{\text {th }}$ and $19^{\text {th }}$ Century Southern Europe (Aldershot, 2005).

Perez, G., 'La Sicilia e le sue strade' (Palermo 1861), pp.1-30 in V.E., Sergio and G., Pera, Un Secolo di politica stradale in Sicilia (Roma-Caltanisetta, 1963).

Pezzino, Paolo, Un paradise abitato dai diavoli. Societa, elites, istituzioni nel mezzogiorno contemporaneo (Milano, 1992). 
Pieri, P., 'La Vaccinazione antivaiolosa nel Regno delle due Sicilie', pp.409-418 in Archivio di Stato per le province napolitane, CVI, 1988, pp. 409-418.

Putman, Robert, Making Democracy Work. Civic Traditions in Modern Italy (Princeton, 1993).

Riley, James C., Rising Life Expectancy. A Global History (Cambridge, 2001).

Scirocco, A., "L'Amministrazione Civile: istituzioni, funzionari, carriere", pp.363378 in A. Massafra (ed.), Il Mezzogiorni preunitario. Economia. Societa e istituzioni (Bari, 1988).

The Evidence At Large, As Laid Before The Committee of the House of Commons respecting Dr. Jenner's Discovery of Vaccine Inoculation; together with the Debate which followed and some observations (London, 1805).

Tisci, Caterina, 'Le Levatrici e la diffusione della vaccinazione antivaiolosa nel Regno di Napoli', Revista Internacional de Culturas \& Literaturas, Dec. 2005, no.3, 1-3.

[Tommasini, Giacomo], Raccolta completa delle opere mediche del Professore Giacomo Tommasini uno dei 40 della Societa' Italiana etc.,etc., con note aggiunte ed emende tipografiche (Bologna, 1836).

Tucci, U., 'Il Vaiolo tra epidemia e prevenzione', pp. 391-428 in F. Della peruta (ed.), Storia D'Italia, Annali 7, Malattia e Medicina (Torino, 1984).

Valenzi, Lucia, "Linee di intervento del governo borbonico nei confronti della poverta'”, pp.1207-1220, in Angelo Massafra (ed.), Il Mezzogiorno preunitario. Economia, societa' e istituzioni (Bari, 1988).

Wilson, R. T., A Narrative of the British Expedition to Egypt (London, 1803).

Woolf, Stuart, A History of Italy 1700-1860. The Social Constraints of Political Change (London-New York, 1991). 